\title{
What's Wrong in Modern Education? Maritain's Warning is Valid Today More than Ever' Andrej Rajský
}

\begin{abstract}
The neo-Thomist philosopher Jacques Maritain, in his pedagogical work Education at the Crossroads (1943), which contains four lectures delivered at Yale University, organically presents his dual vision on which his educational-philosophical considerations are based: awareness of values that make the person one universe and 'the absolute', which is connected with the sense of historical forms and needs. Transhistorical ideals need to be transferred to time structures. Education at the Crossroads deals with pedagogical questions in relation to the nature and aim of the human person, especially in the function of requirements typical for modern civilisation and education. Education is primarily a service of help to human nature that acquires its own developed form in man. Education is an extraordinarily demanding art which, by its very nature, belongs to the sphere of morality and practical wisdom. Maritain identifies seven major misconceptions in the effort to reflect education theoretically, which is, however, directly transferred to defective educational practice: 1. a confusion of ends with means, 2. a false image of the end of education, 3. the focus of education on practice, 4. sociologism, 5. intellectualism, 6. voluntarism, and 7. a belief in the omnipotence of education. The submitted paper presents and analyses Maritain's warnings for education, valid perhaps even more today than at the time they were written.
\end{abstract}

Keywords: Jacques Maritain, philosophy of education, personalism, pedagogy, integral humanism, seven misconceptions

\section{Introduction}

The author of the concept of 'integral humanism' (humanisme intégral), developed in a work with the same title (1936), strives to reconstruct the sense of the finality of human existence with the requirements of the secular organic world. In a free society, the sense of the sacrality of human existence is supposed to be integrated with the profane functions of social structure, which is supposed to eventuate in a harmonic fusion of aims and means. Jacques Maritain demasks modern anthropocentric humanism, which sees the central point and the entire universe in man himself, while man is closed in the sphere of autonomous immanence and, thus, is deprived of the dimension of transcendental bonds, potentialities, and visions of hope. As a contrast, Maritain's integral

1 The paper originated as an outcome of the project VEGA No. 1/0557/16. 
humanism is 'open' and enables man to develop his metaphysically funded dignity at a dialectic axis 'here and now - there and beyond time'.

According to him, in social and political life, it is the question of morality that is transferred to democratic structures in the process of rationalisation aiming at an increase of the level of justice and fundamental freedom. The opposite would lead to the auto-destruction of society. The power of democracy acts in the service of justice and every social whole that would turn this order over is meant to cease (he presents the fall of the Third Reich at the end of the Second World War as an example). In a social organism, the criterion of power is not the state itself, and not even the people of the state, but it is a summary of the supertemporal moral values that stand 'above' the people and the state. ${ }^{2}$ Every society needs a challenge of the vertical development so that it is viable and able to fulfil its basic purpose, that is, implementation of the freedom of every individual in a community with others.

As Maritain said, 'to correspond to this integral humanism, there should be an integral education. ${ }^{3}$ He bases the vision of education on this fundamental vision of man. Education presupposes practical wisdom that is reflected in the formation of the person. Education is an art of service that helps human nature free itself from various empirical determinations. Education provides an achievement of personal and social fullness; thus, it is preparation for a democratic life. Violence and pressure should not be the ends of education, but humanism and science should be, especially the moral acts of an educator who cooperates with the educated. This cooperation is possible because the educator and the educated are similar in their nature ('analogical'). 'It is (...) with the art of medicine that the art of education must be compared.' Medicine handles a living being, an organism that contains inner vitality and an inner principle of health. In other words, 'medicine is ars cooperativa naturae, an art of ministering, an art subservient to nature. And so is education., The natural activity of reason in the one who is learning and the work of intellectual guidance of the one who teaches are dynamic factors of education, however, the main agent, the primary dynamic factor in education is the vital principle that is interior to the educated subject. Based on this pedagogical premise, Maritain rejects so-called punishment education as well as irresponsible permissivism, because the educator is maybe only a 'co-operator of nature', but, at the same time, they are necessary as a moral authority and positive guidance. The outcome of education is supposed to be a man who 'likes to exist' because he feels respected in his personality, he is included in a human community that does not oppress them, he can fulfil his own aspiration for the truth and his own tendency to good.

Maritain's educational thinking was developed in parallel with his anthropological perspective and it may be stated that education is his continual concern - he is aware of the fact that education is a field where the meaning of humanity is fought for. The works devoted explicitly to education ${ }^{6}$ originated under certain historical circumstances and these challenges were reflected by the author. At the same time, fundamental principles and cardinal arguments that appear to

2 The phenomenological studies of Max Scheler and Nicolai Hartmann about moral values, in a complementary way (cf. Eugene KELLY, Material Ethics of Value: Max Scheler and Nicolai Hartmann, New York: Springer, 2011), demonstrate the presence of an 'ultimate reality' which is constituted in the self-activation of individual life-centres and their universal, prespatio-temporal, ground. Maritain, of course, draws on Aristotelian-Thomistic tradition, not on phenomenological approaches. According to him, one's good as a person (not just as an individual) is subordinate to the supernatural end - one's 'spiritual good' is superior to society. Jacques MARITAIN, Education at the Crossroads, New Haven: Yale University Press, 1943, p. 88.

Ibid., p. 51.

Ibid.

6 Jacques MARITAIN, Education at the Crossroads, New Haven: Yale University Press, 1943; Jacques MARITAIN, Pour une philosophie de l'éducation, Paris: Fayard, 1969, $2^{\text {nd }}$ ed. 
be permanent and unchanged can be identified there. There exists essential philosophical-educational continuity between the two works. It's really inspiring to realise the timing of both works. From the point of view of the author, both reflect the events of the 20th century, which symbolically represent two anti-personal cultures: the Second World War (with the totalitarian regimes of Europe), and the year 1968, which is understood as the rise of consumerism and the hedonic entertainment industry. The work Education at the Crossroads (1943) reacts to the first event, and the completed and expanded original work, under the title Pour une philosophie de léducation (1969) responds to the second event. Maritain with his works on education responds to the twofold denial of the person: to totalitarianism in the form of German Nazism and to technocracy, coupled with the consumerism and absolutism of free choice. Both moments make up the historical context of our current educational situation too: the post-communist heritage of totalitarianism and the neoliberal system of training competencies for life in the technological world.

Based on this knowledge, a question whether Maritain's reflections are valid for the present educational situation, even with the distance of several decades, is posed in the submitted analysis. If the neo-Thomist philosopher turns his attention to the problems of modernism and criticises some of the foundations of contemporary reductive humanism, can his challenges be applied to the state of education latently directed at late-modern post-humanism? ${ }^{7}$ This main question is accompanied by another question, namely, what are the particularities of Maritain's educational thinking that are inspiring for contemporary rethinking of education? In my analysis, I draw from the basic hermeneutic framework which allows me to reinterpret the ideational meanings of Maritain's educational philosophy in a shifted context, in which we identify the principal continuity with the circumstances to which our author has responded. Given the abovementioned cultural-temporal parallel between the two situations, I suppose that the image of man in our 'radicalised modernity' requires a philosophical and pedagogical reflection analogous to that of Maritain. At the same time, however, I point to the need for greater theoretical sensitivity to questions of interpersonality and educational dialogue, as well as to the concrete educational event, questions which in Maritain's largely rationalist and perennialist conception ${ }^{8}$ are coming into the background, despite his personalistic effort.

\section{Dual Vision for Education}

In the pedagogical work Education at the Crossroads (1943), which contains four lectures delivered at Yale University, the author organically presents a dual vision on which he bases his suggestive educational-philosophical ideas: the absolute and universal value of man as a person, connected to the sense of historical forms and needs and an emphasis on the transfer of unchangeable and transhistorical ideals to time structures. Education at the Crossroads deals with pedagogical questions in connection to nature and the finality of the human person, in

7 Cf., for example, Francesca FERRANDO, Posthumanism, Transhumanism, Antihumanism, Metahumanism, and New Materialisms Differences and Relations, Existenz. An International Journal in Philosophy, Religion, Politics, and the Arts. Volume 8, No 2, Fall 2013, pp. 26-32.

8 Maritain in his work quotes approvingly other perennialists, Robert M. Hutchins and Mortimer Adler. Gerald Gutek refers to Maritain definitely as a perennialist in educational theory. 'Drawing on Aristotle and Aquinas, perennialists assert that education, like the truth on which it rests, is universal and authentic at every period of history. (...) Perennialist educational theory asserts that human beings, by their very nature, possess a potentiality to know and an inclination to find the truth. This potentiality is enhanced when the individual is brought into contact with the collective experience of the human race through the transmission of the cultural heritage' Gerald L. GUTEK, Jacques Maritain and John Dewey on Education: A Reconsideration. Educational Horizons, Summer 2005. 
the function of requirements typical for modern Western civilisation and education (Europe, USA). 'The Crossroads' of education indicated in the title of the work resides particularly in this tension: in the harmonisation of the permanent moral requirements of the person of man and the requirements and purposes of historical time, that is, specific social and cultural needs. Every human being has a human nature (natura humana), a part of which is the ability of one's own dynamic development that enables one's self-formation and inclusion in civilisation, but also they are accompanied by assisting the pedagogue in this process. Education is foremost a service of help to human nature that acquires its own developed form in man. ${ }^{10}$

Maritain explains that the core of his writing would be better expressed by the title 'Education of Man' - with intentional emphasis on the notion of man, with no further specification (modern, Western, post-industrial, democratic, etc.), because the very question of education needs to be preceded by the question of man, according to the Ancient rule, 'become who you are. Therefore, education is foremost about becoming a man. This definition of the end of education is a permanent memento that has to accompany all thoughts about education and every practical activity. Education is an extraordinarily difficult art that by its nature belongs to the sphere of morality and wisdom.

\section{Seven Falsehoods of Modern (Postmodern?) Education}

Maritain wrote his work at the time of the war crisis, gazing at the philosophical question 'Why?'. Why did the development of European civilisation get into the blind alley of dehumanisation and totalitarianism? Why did democracy find itself in such a state of weakness that its dissolution in populistic collectivistic systems is a real threat? Maritain is looking at the problem from a distance: dehumanising tendencies have their roots in a simplified confused anthropology that eventuates, besides other things, to reductive education.

Maritain identifies seven main falsehoods, misconceptions, or mistakes in the effort for a theoretical reflection of education, which is, however, transferred to mistaken educational practice. ${ }^{11}$ If these sources of pedagogical misconceptions are noticed by an author 75 years ago, the more they should be reflected upon by us, the children of postmodernity. Has something changed in the fundamental criterion setting of pedagogy and education? If not, then Maritain's ideas should be valid impulses for our reflection. By drawing attention to errors, the author does not want to claim that modern society and education are totally spoiled or wrong. His intention is exactly the opposite. In identifying mistakes, he is using a negative method: to define what good education is not, in order to show what good education is. This method allows him to highlight the still valid - eternal - possibilities of education given by human nature, regardless of historical and social circumstances. By pointing to educational mistakes, he points to cliffs, traps, and risks, that we in education should be careful and not cause harm. The individual misconceptions, which I present and analyse below, can be used as a guide to assist teachers in critical reflection on their educational practice, regardless of a certain historical distance.

9 Maritain does not distinguish between Western and Eastern Europe and their individual countries; his reflections are directed towards the overall cultural situation of Western civilisation. In the context of European integration and even more massive globalisation of the past decades, I do not hesitate to apply his warnings to the countries of Central and Eastern Europe, too.

10 Although Maritain himself calls for 'one to do and the other not to neglect' - to reflect educational goals and not to ignore the means, indeed he does not care of the educational means (psycho-social development theories, etc.) and de facto ignores them.

11 MARITAIN, Education..., pp. 3-36. 


\section{The first misconception: a-teleologism ${ }^{12}$}

The biggest misconceptions are related to the ends of education. If education is an art (techné), then it dynamically moves towards its own object that is supposed to be realised. Thus, there is no art without finality, and the vitality of every art depends on energy with which it moves towards its target without being focused predominantly on partial aims and stopping at them or identifying with them. The first misconception of education rests in disregard for its ends, or in confusing ends with means. If for the love of means we focus in education primarily on means, the art of education loses its practical wisdom and efficiency. According to the author, contemporary education errs in insisting on the primacy of means over ends and it results in the supressing of the finality of education. 'The means are not bad. On the contrary they are generally much better than those of the old pedagogy. The misfortune is precisely that they are so good that we lose sight of the end. ${ }^{\prime 3}$ The means are even as good as distracting us from the ends. The weakness and weak efficiency of contemporary education is such a result of our attachment to excellent educational means and tools that we are unable to apply in order to reach the aim, asserts the author.

Maritain observes that pupils are examined by various diagnostic tools and tests: we know their needs, analyse their psyche, construct perfect educational methods, however, regardless of the final end, this is similar to a doctor who is excited about precise analytical techniques and tools, but in the meantime the patient is losing his life. The only authentic end and

primary aim of education in the broadest sense of this word is to 'form a man' or, rather, to help a child of man attain his full formation or his completeness as a man. The other aims (to convey the heritage of culture of a given area of civilization, to prepare for life in society and for good citizenship, and to secure the mental equipment required for implementing a particular function in the social whole, for performing family responsibilities, and for making a living) are corollaries and essential but secondary aims. ${ }^{14}$

The scientific improvement of pedagogical means and methods is evident progress, however, the greater attention it receives, the greater strengthening of practical wisdom and dynamic focus on the end is required.

As noted by the educational theorist Wolfgang Brezinka, today's pluralistic society lacks consensus on what should be the ultimate value which should relate the education. The traditionalised ideals of man are accepted rather intuitively in pedagogy, but pedagogy does not deal with them scientifically. 'For the people and their community they are more urgent than empirical-technological problems, which are concerned with pedagogy. Therefore, we need to add some normative philosophy of education to the pedagogy. ${ }^{15}$ Since around 1968, the system of values has changed in Western society from nomocentric to autocentric and the related focus of education is primarily on individual 'self-development. ${ }^{16}$ Curricular educational goals have been the subject of negotiation for obtaining a professional and political consensus; the philosophical teleology of

12 The designation of the first misconception as a-teleologism, the second misconception as pseudo-teleologism and the seventh misconception as pan-didacticism does not come from Maritain, but it is mine. I was inspired by this article: Marek WIESENGANGER, Perspectives of Philosophy of Education according to Jacques Maritain, Acta Facultatis Paedagogicae Universitatis Tyrnaviensis, Ser. D, 2011, no. 15, p. 38.

13 MARITAIN, Education..., p. 3.

14 Jacques MARITAIN, The Education of Man. The Educational Philosophy of Jacques Maritain, Notre Dame: University of Notre Dame Press, 1967, pp. 50-51.

15 Wolfgang BREZINKA, Filozofické základy výchovy, Prague: Zvon, 1996, p. 11.

16 Ibid., p. 24. 
education has disappeared from the discourse. I agree with Brezinka when he claims that 'full personality development', 'self-development', or 'self-actualisation' cannot be the main goal of education: they are rather processes that have no normative value. ${ }^{17}$ Such a goal can only be the ideal of man, philosophically reflected in the context of a culturally settled anthropological order. In this sense, Maritain's warning appears actually valid. The preparation of teachers must include the best pedagogical methods as well as a philosophical education. Such a preparation must do so, above all, by means of the education of intellect and reason.

\section{The second misconception: pseudo-teleologism}

The second misconception does not reside in ignorance of the end but in a confused or incomplete image of the nature of the end. ${ }^{18}$ If the end of education is to help and guide a child towards their own human dignity, ${ }^{19}$ then education cannot escape philosophical problems and difficulties, because it naturally presupposes a philosophy of man and it requires the obligatory answer to the philosophical question 'Who is man?'

As Maritain underscores, this question is answered differently by a strictly scientific concept of man and by a philosophical-religious concept of man. The idea of man offered by experimental science abstracts from the ontological content of man, and remains completely in the area of sensual verification (positivism and neo-positivism). The strictly scientific notion of man tries to assemble outer measurable and observable data, while resigning on questions related to essence, spirit, finality, and values from the very beginning: Does the soul exist or not? Does spirit exist or does only matter exist? Do we have free will or is everything determined? Does aim exist or are there only coincidences? Do we focus on values or only on facts? On the contrary, the philosophical-religious concept of man is ontological, it is not completely verifiable in the space of sensual experience, and it turns to essential and inner qualities and to the intellectually knowable depth of being that we call man.

'The child is so well tested and observed, his needs so well detailed, his psychology so clearly cut out, the methods for making it easy for him everywhere so perfected, that the end of all these commendable improvements runs the risk of being forgotten and disregarded. ${ }^{20}$ The strictly scientific notion of man offers factual and useful information that helps to improve educational means and methods, however, it is not capable of explaining the primary bases and principles of education because education needs to know, first of all, who man is, what his nature is, and what scale of values he existentially implies. Pupils, the subjects of education, are not only a summary of physical, biological, and psychological phenomena - even though knowledge of them is needed and necessary - they are the children of humans, indeed, they are humans with their own ontological mysteriousness and finality. The scientist (positivist) rejection of these facts and values, without which education loses its humanistic sense, leads to a situation where education turns into 'the training of an animal for the utility of the state. ${ }^{21}$ This implies that education requires an integral and complete notion of man, localised in a relationship to the absolute.

The question 'What is man?' is answered by the Greek and Judaeo-Christian tradition as follows:

17 Cf. ibid., p. 28.

18 Similarly, 'apparent educational goals' and 'insufficiently defined educational goals' are also criticised by Wolfgang BREZINKA in his above quoted work, pp. 27-29.

19 'Thus the prime goal of education is the conquest of internal and spiritual freedom to be achieved by the individual person, or, in other words, his liberation through knowledge and wisdom, good will and love' MARITAIN, Education..., p. 11.

20 Ibid., p. 3.

21 Ibid., p. 5. 
man is an animal gifted with reason whose dignity is given by intellect; man is a free individual in a personal relationship to God, whose justice is given by voluntary fulfilment of God's law; and, finally, man is a vulnerable and sinful being, called to life and freedom, whose highest perfection is given by love. Thus, man is a person who grasps himself through reason and will. The existence of a person is not only physical, but also spiritual, created by knowing and love (sophia - philia). Maritain differentiates two dimensions in man: personality and individuality. Individuality is created by a material principle; an individual is a part of the human species, a part of the physical universe, a part of the battlefield of empirical powers and influences (natural, ethnical, historical, social, etc.). From this point of view, man is a sensual and rational animal. Education is oriented on this dimension of man: it trains their psycho-physical skills, determines their reflexes and memory. Education, however, is also an 'awakening' of humanity, that is, what transcends animality. Personality is the dimension that enables it - through intellectual knowing and spiritual love. Thus, the permanent motive of educational activity is the development of certain spiritual powers of a child: intellect and free will. The true finality of education is thus the acquisition of inner spiritual freedom through knowing and the development of the ability to love.

Making formal mention of the dignity of the human person seems natural and obvious to the educational enterprise today. The same is true of the issue of love, the generous and selfless relationship to the other person (so-called pro-social behaviour). However, ensuring these most noble values and aims of education across the curriculum is another matter. It requires the cultivation of the intellect, of course, but - as Aristotle writes ${ }^{22}$ - intellectual effort in (moral) education is not enough. Knowledge as such does not automatically mean that the pupils will be virtuous. Aristotelically speaking, man does not make man to be man, but taking him from nature makes him to be a good man. The human good includes the choice of the human good. The choice requires - in addition to or before the intellectual work - real training in specific situations of life. 'Virtues arise in us, (...) nature gives us the capacity to acquire them, and completion comes through habituation. (...) Virtues, however, we acquire by first exercising them. ${ }^{23}$ Nevertheless, Maritain does not include the moral aspect of education that fits with habituation, exercising, and interpersonal experience ('ability to love', the virtue of charity) into main school educational aims. This deficit shifts its concept to the pedagogical intellectualism, although in the fifth misconception he warns of it, albeit in a different interpretation.

\section{The third misconception: pragmatism}

The third misconception of education is pragmatism. The emphasis on acting, praxis, is certainly beyond doubt, since life is acting. However, pragmatism loses the view of the aim due to practice. Contemplation of the whole of human life that is aspired to by the human spirit is lost to the pragmatic view. Life exists due to an aim, thanks to which it is worth living. Acting or utility are not a sufficient final goal. Pragmatism (and within it behaviourism and instrumentalism) defines human thinking as an organ by which we react to stimuli and current situations of the environment equally to other animals. Maritain, however, emphasises that human thinking does not start only with answers to problems that need to be solved, but it starts with an insight, an effort to understand what things are, thus, thinking is not determined by pragmatic sanction but by a much deeper desire to enlighten experience and to prove the inspected notion of the world,

22 'With regard to virtues, knowledge has little or no weight'. ARISTOTLE, Nicomachean Ethics II.5 1105 b2.

23 ARISTOTLE, Nicomachean Ethics II.5 1103a14-18. 
that is, the truth rationally. The principle of human acting is thus love towards the cognised truth. ${ }^{24}$ Human acting is meaningless without a belief in truth.

Maritain's judgment against pragmatism is uncompromising: a pragmatic philosophy of education stops at the level of skills and usable knowledge, but eventually it presupposes a sceptical foundation that does not enable an understanding of the world and man in his whole. The school youth who have the latest educational techniques and scientific methods at hand are made to think that the ideas of truth and wisdom do not belong to the area of education. Pragmatic scepticism causes the loss of trust and self-esteem in pupils, it weakens life hope. ${ }^{25}$

The Maritain expert Mario O. D'Souza refers to this topic:

I believe that Maritain provides a deterrent to pragmatism. These various hierarchies [philosophical and theological, note of A. R.] reveal the created order as well as the order revealed to human persons through the powers of knowledge and intelligence, good will and love. (...) These hierarchies are diametrically opposed to pragmatism that is exclusively reliant upon the present and to what is expedient in the present. ${ }^{26}$

Our author notes that modern pedagogy took a giant leap in the effort to diagnose and analyse the learning subject precisely. However, if the very content of education with respect to finality is neglected, the purpose of education and school is being deformed. The cult of educational methods and means eventuates to 'psychological adoration of pupil ${ }^{27}$ (psychologism, paedocentrism) ${ }^{28}$ at the expense of the object of education. A pedagogue is constantly experimentally reconstructing their educational aims, because they do not have the final complex purpose, and their aim is only growth and development. ${ }^{29}$ The pragmatic expertise of the pedagogue does not reside in the art of education but in applying pedagogical formulas. The activity of the pedagogue thus resembles the activity of an architect who knows the laws of physics and quality of materials, however, has no idea of the final building that is being built.

It should be emphasised, however, that when Maritain rejects pragmatism, he does not reject experience as such. On the contrary, 'education and teaching must start with experience, but in order to complete themselves with reason. ${ }^{30}$ His philosophy is grounded upon the foundation of sense knowledge, nevertheless, he defends the experience, which should be spiritualised through faculties of knowledge and intelligence, good will and love. It is interesting that John Dewey, a representative of instrumentalism against which Maritain has reservations, points out similarly: 'The belief that all genuine education comes about through experience does not mean that all experiences are genuinely or equally educative. Experience and education cannot be directly equated to each other.' ${ }^{31}$ D'Souza states that at the present, 'the educational stress upon personal

24 MARITAIN, Education..., p. 12.

25 Ibid., p. 14.

26 Mario O. D’SOUZA, Jacques Maritain's Seven Misconceptions of Education: Implications for the Preparation of Catholic School Teachers, Journal of Catholic Education, 5 (4), p. 443.

27 MARITAIN, Education..., p. 14.

28 Paedocentric psychopedagogy in Europe has been developed by the 'movement of new schools' (Éducation nouvelle). Classical representatives of this position include the founder of Ligue internationale pour léducation nouvelle (1921) Adolphe Ferriére (1879-1960), Édouard Claparéde (1873-1940) with his concept of éducation fonctionnelle, Jean-Ovide Decroly (1971-1932) focusing on 'biosocial needs' of the child, Célestin Freinet (1996-1966) with his child-centred 30 pedagogical constants, and others. At the beginning of experimental psychopedagogy in the USA stands Edward Lee Thorndike (1874-1949), behaviourist approach in education ('technology of teaching') was developed by Burrhus Frederic Skinner (1904-1990).

30 MARITAIN, Education..., p. 46.

31 John DEWEY, Education and experience, New York: Collier Books, p. 25. Quoted in Mario O. D’SOUZA, Maritain’s Philosophy of 
experience is often unaccompanied by a corresponding stress upon those human faculties which draw out the educational value of experiences, thus being able to distinguish between good and harmful experiences.' ${ }^{32}$

Therefore, according to my deduction, the experiential element is not the problem of education, nor is it even necessary; the problem is the separation between experience and intellectual reflection. 'School game' and certain 'learning by doing' that reduces learning to experience for experience (including the current educational concept of 'serious games', etc.), without the necessary assessment reflection, does not practice real education. And, let me say that the opposite is also true: intellectual exercises, without the involvement of total personal experience, will remain self-assuring instrumental calculus. There is a certain selfishness in learning if it is separated from the 'emotional and affective tonus of life'. ${ }^{33}$ Both solutions bring the pupil to the illusion of self-sufficiency, to a false autonomy. Only the clear and reflected hierarchy of values in education, as suggests Maritain, can save the integrity of human education.

\section{The fourth misconception: sociologism}

The fourth misconception is sociologism, that is, the absolutisation of the society. It is a model of education in which social determination is considered the highest rule and the only criterion of education. For Maritain, the essence of education, however, does not lie in the preparation of a future citizen for conditions and interactions of social life, but in the first place, in the formation of a man, thus, a citizen, too. Education for life in a community implies foremost the education of a person and this education is practically impossible without being carried out in the centre of community life, where civic wisdom is awakened in a pupil and social virtues are developed.

Education of a person should not be understood as individualistic education aimed at the punctilious education of an individual as it used to happen in the past, says Maritain. Modern pedagogy is justly proud to have brought education closer to specific experience and included interest in social themes in it. However, if it is to follow its true aim, it needs to understand that social or civic education should not be aimed at the blending of man with society, but it is supposed to be education of the inner centre of personality, the living source of conscience, from which spring ideals and generosity, a sense of lawfulness and friendship, respect to others, etc. At the same time, it leads to deeply rooted independence from public opinion. 'The essence of education does not consist in adapting a potential citizen to the conditions and the interactions of social life, but rather in making a man, and by this very fact in preparing a citizen. ${ }^{34}$ Effort for a specific life of a pupil becomes an illusion if their attention is spread amongst 'practical' manuals, psycho-technological aids, and useful activities at the expense of an authentic specific life of intelligence and spirit that gives freedom, joy, and beauty.

From today's perspective, postmodernism pays great attention to how the social sphere influences and transforms human subjectivity. The deconstructionism (Jacques Derrida) and 'weak thinking' (Gianni Vattimo) of postmodernism have led the professional community and public opinion to believe that human nature is an illusory concept. In this context, the human person has ceased to be an autonomous and forming entity, becoming a psycho-social 'self' whose identity is dependent on social and cultural expectations. Deconstructionism refers to the notion of

Education and Christian Religious Education, Journal of Catholic Education, 4 (3), p. 393.

34 MARITAIN, Education..., p. 15. 
deferral, of 'being late' in regard to 'what is': our thought about it occurs after the 'being' itself. On this notion Jacques Derrida built his system of interpretation where the central thesis is that nothing really is, that 'being' as construed by Western metaphysics is an illusion. ${ }^{35}$ The postmodern nihilist Vattimo adds that we suppose the category of universality, because if it was not an integral being and a distinguishable subjectivity, every idea would lose certainty. But this certainty, which seems to secure the stability of the whole scenario, is very uncertain, being a rather superficial bond, which allows us to see the world in unity. The significance of things is rather the result of a chain of cultural and historical logical operations that we tend to consider to be a uniform stream. The power of society forces us to seek in social communication a common reference plan in which we can unite the meaning of our statements. This common plan, however, is common because it does not belong to anyone, it is a game, an artificial product, which we all agree on as a neutral compromise. ${ }^{36}$

The post-metaphysical situation takes us away from the personal dignity and uniqueness of each individual, encouraging us to consider the pupil as a result of socio-cultural conditions. The 'self' is finally defined as a 'cultural construct, ${ }^{37}$ which is a problem, because under such conditions there is no normative or indicative ontology, and even biological determinations (for example, gender) are interpreted as an ambiguous social choice. ${ }^{38}$ Here, we could paraphrase the wellknown Dostoevsky thesis: If there is no being, everything is permitted ${ }^{39}$ - there is no limit and there is no fundamental educational finality.

The risks of social determinism in education have also been identified and predicted by Jacques Maritain. He explains that the danger of sociologism is the subordination of the aims of education to the aims of the society, and thus educational collectivism. Education is subject to trends that will probably develop in the collectivity of the society and it becomes a tool of the predominant interest of social power. The content of education, set through a social reconstruction of aims, will eventually be subject to precarious factors of the environment that need to be controlled by political power. ${ }^{40}$ Teachers have neither to make the school into a stronghold of the established socio-political order nor to make it into a weapon to change society. ${ }^{41}$

However, if we claim, together with Maritain, that the final aim of education is the development of man as a human person, then the creative and innovative power of education must not be supressed by the preordained social norm. The development of man who is an object of the art of education is an infinitely more noble and complicated work of art than the work of architecture or social urbanism since it touches upon the freedom of spirit and its permanent creative reconstruction.

\section{The fifth misconception: intellectualism}

The fifth misconception is called intellectualism. It is a misconception that stems from an exaggerated emphasising of the partial spiritual mightiness of man - his intellect. Intellectualism identifies

35 Jacques DERRIDA, Of Grammatology, Baltimore: Johns Hopkins University Press, 1976. Derrida wants to destroy the notion of language on which Christianity has been built. Cf. Floyd MERRELL, Deconstruction Reframed, West Lafayette: Purdue University Press, 1985.

36 Gianni VATTIMO and Pier Aldo ROVATTI (eds.), Il pensiero debole, Milano: Feltrinelli, 1983, pp.42-51.

37 Robin USHER and Richard EDWARDS, Postmodernism and Education, London: Routledge, 1994, p. 16.

38 Cf. Anne FAUSTO-STERLING, Sexing the Body, New York: Basic Books, 2000, p. 3.

39 Dostoyevsky expressed the thesis, with the words of Ivan Karamazov, his character in the novel The Brothers Karamazov: 'If God does not exist, everything is permitted.

40 MARITAIN, Education..., p. 15.

41 MARITAIN, The Education of Man ..., p. 59. 
the peak of knowledge perfection with dialectic, rhetoric, or scientific-technological skill. Maritain identifies two kinds of intellectualism: the classical rhetoric (eristic, in the manner of the Greek Sophists, or snobbery ${ }^{42}$ ) and modern technological (which we might call 'professionalism' or 'technocratism'). Both forms of intellectualism abandon universal values and prefer practical and operative functions of reason.

We could ask whether Maritain's position is also a form of intellectualism, respectively, rationalism, as he raises intellectual education to the highest degree of aims to which all other educational aims are to be subordinated. It seems that the answer to this question will be positive, although - as Maritain claims - 'it is better to will and love the good than simply to know it. ${ }^{43}$ On the other hand he believes 'that intelligence is in and by itself nobler than the will of man, for its activity is more immaterial and universal. ${ }^{44}$ The condition of immateriality and universality is a necessary condition of truth for Maritain, but so he postpones to the secondary site the opportunity to draw from all concrete sources of educational wisdom (interpersonal relationality, acts of altruism, experience of limits and crises, art communication, etc.). This conviction of Maritain, on the other hand, encounters his personalist position, according to which the significance of the person lies in their relationships with others (cf. the philosophies of E. Mounier, F. Ebner, M. Buber, E. Lévinas, etc.). The dialogic dimension of human existence as a person in Maritain's educational theory does not have an adequate position.

Maritain's critique of intellectualism focuses mainly on the problem of specialisation in education. The specialisation is increasingly emphasised at the expense of general education and moral cultivation of man. Maritain speaks of the cult of specialisation that dehumanises human life, ${ }^{45}$ because it orients it exclusively on efficiency and material values (a specialist or expert who is commercially wanted). Man is thus likened to an animal, since an animal is specialised in application of its knowledge exclusively in fulfilment of particular tasks that enable it to survive (for example, bees and the collecting of honey). A specialisation that does not lead pupils to the ability to give general judgements on politics, morality, and meaning corresponds to the animalisation of man. According to him, the tendency to a specialised model of education is based on a materialistic philosophy of life that reduces the life of man to producing, to economical values, and scientific discoveries subordinated to them, while leisure time should be filled with superficial fun and a vague religious sentiment.

Our author points out that such a conception of education is dangerous also for democracy, because democratic ideals demand faith in spiritual energies, whereas the progressing technological specialisation eventuates to state technocracy and a lack of 'men of judgement'. How can a common man judge common good if he is able to judge only what is within the narrow horizon of his special competence ${ }^{46}$ Political activity and political evaluation may thus become a monopoly sphere of exclusive experts, state technocrats, at the expense of freedom and happiness of people. The democratic conception of life requires predominantly free education for all and a general humanistic development in all layers of society that will also provide the ability of the adaptation of individuals to new challenges and circumstances.

Konrad Paul Liessmann, the current Austrian philosopher of education, in his book The Theory

42 D'SOUZA, Jacques Maritain's Seven Misconceptions..., p. 446.

43 MARITAIN, Education..., p. 22.

44 Ibid.

45 'As the life of bees consists of producing honey, the real life of man would consist of producing in a perfectly pigeonholed manner economic values and scientific discoveries, while some cheap pleasure or social entertainment would occupy leisure time (...) The overwhelming cult of specialization dehumanizes man's life.' MARITAIN, Education..., p. 19. Ibid. 
of Miseducation (in German: Theorie der Unbildung. Die Irrtümer der Wissensgesellschaft. Wien: Paul Zsolnay Verlag, 2006, in Czech translation since 2008) unmasked the current 'game of education', which voluntarily and with cynical self-irony rejects Humboldt's ideal of intellectual, educated man - for whom education is the highest task of our being - in order to get along with the adoption of a manual to monetise useful information. Liessmann says that the aim of the actual effort of the society is miseducation. The plethora of knowledge charges a person with a disadvantageous ballast, a burden which hinders social interaction, commercial fluency (cashflow), political correctness, and moral coherence.

In contrast to constant assurance about the value of knowledge, just knowledge is, generally, not particularly prized, because it has been long overdue with severity imposed on knowledge. (...) Since knowledge is defined by external criteria such as expectations, applications and performance as with a manufactured product, it is clear that where it does not meet these criteria, it must be quickly liquidated. ${ }^{47}$

Miseducation as a goal does not mean absence of formal intellect, a lack of cognitive power, but it means reducing the knowledge horizon to a segment immediately visible from the commercial information aspect. The current intellectual should respond to external factors such as market, employability, site quality, and technological development. Such an 'intellectual' is in fact an overconfident ignorant. ${ }^{48}$

Thus, I agree with Maritain: the preparation of school teachers must consider the implications of the error of exaggerative specialisation and technocratisation. The inevitable specialisation that the workplace demands will be devoid of humanism and wisdom if does not contribute to the humanising process and to growth in personhood.

\section{The sixth misconception: voluntarism}

The sixth misconception, voluntarism, grows from the exaggerated preference of another spiritual mightiness of man - will. The classical definition of voluntarism turns the inner order of man upside down, subordinating reason to will (Schopenhauer ${ }^{49}$ ), submitting man to a dominance of irrational powers. ${ }^{50}$

Maritain explains that this conception results in two different models of education - it is either oriented on the will of the young man and he is disciplined according to national or state norms, or it leaves space for the free expansion of natural forces, inclinations, and instincts. The first model was successful in school drill and training in youth organisations of totalitarian states, for example, in Nazi Germany. A negative consequence was the destruction of the sense of truth, of poetics of language, and a soft morality of thinking students. The second model of voluntarism is demonstrated in modern liberal countries as a weakening of the power of the intellect (and negative impacts of intellectualism) in favour of the right to 'free opinion'. However, this right is dependant on the willingness to believe a certain opinion.

\footnotetext{
Paul Konrad LIESSMANN, Teorie nevzdělanosti. Omyly společnosti vědení. Prague: Academia, 2008, p. 95.

8 Ibid., p. 53.

49 Schopenhauer characterises the world as Will, which is not the principle of self-consciousness and rationally-infused will, but a mindless, aimless, non-rational impulse at the foundation of our instinctual drives. The will is the being devoid of rationality, even in humans. See in the work: Arthur SCHOPENHAUER, Die Welt als Wille und Vorstellung, Stuttgart: Reclam, 2013. After Schopenhauer, also for some $20^{\text {th }}$ century thinkers, the universe appears to be an essentially irrational place and the instinctual forces are irrational, and yet guiding, forces underlying human behaviour.

MARITAIN, Education..., p. 20.
} 
In general, the primacy of will in politics identifies authority with power, and the primacy of will in thinking reduces everything to self-willed opinions and academic conventions. After all, education resides in acts of faith, while a principle of this faith may be our personal preference. The primacy of will is projected to postulates of will (I want because I want, a demand of subjective preferences) regardless of the truthfulness of statements. Voluntarism causes knowledge not to be based on a rigorous intellectual effort but on a convention, a social agreement, or on irrational motivations.

Contemporary social philosopher Gilles Lipovetsky sees behind the so called 'honesty' of postmodern man an acute hedonism, which has become, under the influence of mass consumption, the central value of our culture. The life cycle goes through a rapid changing of phases of various lifestyles; the individual doesn't search for his own identity through them (that he would stay with), but he is immersed in the current experience of the exploration of enormous possibilities. Lipovetsky ${ }^{51}$ evaluates the second half of the $20^{\text {th }}$ century as the epoch of radicalising individualism and narcissism entrenching as a pattern of mass culture and lifestyle. The process of individualisation 'has fronted personal actualisation and the respect to subjective particularity and a unique individuality as a fundamental value. (...) The right to be absolutely yourself and to enjoy as much as possible (...) is just the backmost manifestation of the individualistic theory.52 The second model of voluntarism, as stated by Maritain, acquires this form of individualistic narcissism, in so-called 'post-moralistic society'. Do we have adequate moral education to respond to this situation?

While moral education is an important dimension of institutional education, Maritain reserves it exclusively in the field of reason: the school imparts moral education through the enlightenment of the intellect. Maritain hesitates about the suitability of character formation in schools and doubts its success. He fears a voluntarist misuse in the school transfer of moral contents, having totalitarian experiences in former Germany. Nevertheless, I cannot agree with Maritain on this issue, since adequate character education, based on methodically facilitated interpersonal experience, coupled with the previous and consequent value/moral reflection, certainly does not slip into voluntarism..$^{53}$ Finally, he further recognises the eminent importance of forming the virtuous character of a person, especially 'the virtue of charity - supreme virtue. ${ }^{54}$ The student is a person who grows towards personhood by virtue of 'psychosomatic unity. ${ }^{55}$

However, Maritain points out the necessity of the rule of reason over will. 'We must understand that without abstract insight and intellectual enlightenment the more striking experiences are of no use to man, like beautiful colours in the darkness. ${ }^{56} \mathrm{He}$ does not aim to devalue the role of will, the ability to develop virtues, to love others, and to face difficulties. Reason and will actively intersect each other, and in education they either support each other or weaken each other. Education of will without education of intellect eventuates to blind voluntarism. Education of intellect without education of will condemns a young person to sterile or purposive intellectualism.

51 Gilles LIPOVETSKY, Lère du vide: Essais sur l'individualisme contemporain, Paris: Gallimard, 1983; in Czech translation Gilles LIPOVETSKY, Éra prázdnoty. Úvahy o současném individualismu, Prague: Prostor, 2008.

52 LIPOVETSKY, Éra prázdnoty..., p.11.

53 Cf. Emily LOMBARDI, Character Education: Integration of an Ancient Theory, ESSAI Vol. 7 (2009), Article 32; among empirical studies, for example, Martin BRESTOVANSKÝ, Prosocial Moral Reasoning and Behaviours: the Role of Ethics Education, Forum Pedagogiczne 2016/2 cz. 1.

54 MARITAIN, The Education of Man ..., p. 53.

55 Ibid., p. 52.

56 MARITAIN, Education..., p. 16. 


\section{The seventh misconception: pan-didacticism}

The seventh misconception is the belief that it is possible to teach everything through schooling. The most important thing in education is something that cannot be educated and even less schooled. Maritain argues that it is impossible to teach everything through schooling. For instance, it is impossible to teach and learn the virtue of practical prudence (prudentia), which is an inner vital judgemental ability of intellect supported by will - no schooling is able to replace it. Experience that is a non-communicable fruit of suffering and memory and that forms man cannot be taught at any school and on any course. There are courses of philosophy, however, there are no courses of wisdom. Wisdom is acquired through spiritual experience and the practical wisdom of 'the elders' cannot be scientifically demonstrated.

According to Maritain, the most important things in life and education of man are intuition and love. Intuition and love are not unerring and not always precise, however, neither the flame of life nor the flash of heaven are able to be kept cooped up in concepts. Intuition and love are values that escape schooling, they are gifts of freedom. Through schooling, students are supposed to learn what intuition and love mean, or what is a good object of knowing and loving, however, enthusiasm and passion cannot be taught, they can only blaze up from the very fount of a person..$^{57}$

Maritain also does not accept models of teaching and education that embrace informal elements allowing one to touch experientially one's own limits, to experience the fragility of the human relationship, to know the good of the deeds of solidarity and of personal help. In this way, I think, he limits not only the possibilities of education, but also the possibilities of philosophical thinking about education. As a certain counterbalance, I quote three statements from well-known figures of personalist philosophy, to which Maritain also claims allegiance. One of the most famous European personalists Emmanuel Mounier wrote, 'The basic impulse in a world of persons is not the isolated perception of self (cogito) nor the egocentric concern for self, but the communication of consciousness. (...) We should prefer to call it the communication of existence, existence with the other, perhaps we should say co-existence. ${ }^{38}$ American philosopher Joseph H. Oldham claims, 'It is through our responses to other persons that we become persons. It is others who challenge, enlighten and enrich us. There is no such thing as the isolated individual (...) Reality is the lived relation. ${ }^{59}$ And finally one more formulation from the philosopher of dialogue, Martin Buber:

The individual is a fact of existence in so far as he steps into a living relation with other individuals. The aggregate is a fact of existence in so far as it is built up of living units of relation (...) I call this sphere, which is established with the existence of man as man but which is conceptually still uncomprehended, the sphere of 'between'. Although being realised in very different degrees, it is a primal category of human reality. This is where the genuine third alternative must begin. ${ }^{60}$

57 'The school should educate the whole man. A significant role belongs to ethics and formation of character, as well as mans' will. Nevertheless, Maritain does not consider moral formation to be a proximate goal of school education, but he emphasizes its significance in school through education and the creation of a personalistic relationship between the teacher and pupil.' Pavol DANCÁK, The personalistic view of education in the philosophy of J. Maritain, Studia Ubb Theol. Cath., LIX, 1-2, 2014, p. 140.

58 Emmanuel MOUNIER, A Personalist Manifesto, London: Longmans, Green and Co., 1938. In Italian translation: Emmanuel MOUNIER, Che cosè il personalismo? Turin: Einaudi, 1975, p. 62.

59 () Joseph H. OLDHAM, Real Life is Meeting, London: The Sheldon Press, 1958, available from: http://www.chebucto.ns.ca/Philosophy/ Sui-Generis/Berdyaev/essays/rlm.htm, cited $6^{\text {th }}$ January 2019.

60 Martin BUBER, Between Man and Man, Boston: Beacon Press, 1957, p. 202. 
Obviously, the main goal of the school is to cultivate the intellect, but postponing opportunities to cultivate character exclusively in the extracurricular sphere, I find it unjustified.

In any case, as Maritain points out, there is a great extracurricular sphere of life that shapes man stronger than education - it is the sphere of human activities, work, daily efforts, experience of friendship and love, social morals, law, wisdom embodied in common traditions, the bright shine of art and poetry, the impact of feasts and liturgical ceremonies. All of this in line with the belief that education does not dominate, it serves.

\section{Basic Dispositions of Education}

In order not only to criticise and judge misconceptions, the paper will point out constructive possibilities which human nature, hidden in the core of each person, provides the art of education with. The human being that is formed to a true human person, perfect in the ability to know and love, contains in himself an inner principle of reason and freedom. This human being, however, needs the help of a teacher who is able to support the basic natural dispositions of a young man through education and disciplining. If nature and the spirit of a child are the major agent of education, then the base of an educational work will be the support of basic dispositions of this major agent. Basic dispositions are rooted in nature but may be deformed, therefore, it is necessary to cultivate them carefully. J. Maritain describes the following five natural dispositions of man, being five basic relations that need to be educationally cultivated. ${ }^{61}$

1) Relationship to the truth Love for the truth is the primary tendency of every rational nature. The desire to uncover reality, to know the truth is inherent to every child. The task of education is to support interiorisation - to release the deep spiritual dynamics coming from radical intellectual 'preconsciousness', the natural thirst for knowledge and understanding that is present in everyone. Maritain speaks of the preconsciousness of spirit that is located under the surface of notions and logical relationships - 'the sources of knowledge and poetry, of love and truly human desires [is] hidden in the spiritual darkness of the intimate vitality of the soul. ${ }^{62}$ Rational knowledge, before it is formed and expressed in notions and judgements, comes from an encounter of the intellect with the world of images and emotions, and from this encounter it jostles to the level of rationally graspable contents. These particular spiritual dynamics of preconsciousness of a pupil is entered by a pedagogue through his mastery of education. They help to distinguish between spiritual preconsciousness and irrational unconsciousness, to purify and free creative spiritual aspirations from self-willed natural pressures.

2) Relationship to good and justice Love for good and justice is natural to man. A young man is excited about heroic acts for the sake of justice and the victory of good over evil. This tendency of will, too, equally to the above-stated tendency of reason, springs from the spiritual depth of a person. The superficial acts of will are focused either on harmonisation with posed outer normativity (outer discipline and order) or an achievement of one's own interests and indulgences (selfish satisfaction). Will as a radical spiritual power comes from the desire for freedom and creativity. The task of an educator is to help to release this soft energy from the trap of animal natural commands bringing irrational satisfaction and to bring the pupil to an uncovering of their spiritual sources of a humane life and freedom. The teacher lets the pupils look in and examine the spiritual, freeing the potentiality of intellect and will as contrasted to the determining pressures

61 MARITAIN, Education..., pp. 36-38.

62 Ibid., p. 41. 
of the natural and social world. The accomplishment of these pedagogical aims is not possible to be carried out by perfect didactic procedures and techniques, nor it is possible to measure them by tests and evaluations. Their accomplishment depends on the intuition and pedagogical genius of the teacher who meets the spiritual mightiness uniquely present in the personalities of pupils.

3) Relationship to existence This natural disposition is often disturbed and deformed by egoism and the human inclination to corruption. Openness to existence is so fundamental in man that it is completely elementary and simple. Maritain describes it as a positive approach of man to being, as an approach of the one who likes existing and is not ashamed to be, the one who is able to stand his ground in existence and for whom to exist and accept natural limitations of existence means to agree with life simply and directly. Plants and animals behave like this, however, only in the physical area. In man, this natural behaviour needs to enter the sphere of mental life and acquire moral consistency in it. This disposition is still far away from the virtues of generosity and humility, but it represents their natural field. 'Fear and trembling' are undoubtedly a great part of the experience of human spirit, but they are a wrong beginning of education. Education, on the contrary, needs to start in joy and thankfulness to life.

4) Relationship to work The sense of work well-done is another natural disposition of education. The attitude of openness to existence refers to the attitude of man to work. Maritain does not speak about the simple willingness to work hard, since laziness is inherent in man. He speaks of a deeper and more human respect for work, a sense of faithfulness and responsibility in relation to work..$^{63}$ The relationship to work is the primary natural inclination to self-discipline: if the relationship to work is being disturbed, the essential condition of human morality is fading away. 5) Relationship to others This basic disposition may be called the sense of cooperation. According to Maritain, it is equally natural as the tendency towards life together. If man is a political animal, it means the naturally required society is realised thanks to his free agreement. A person requires the communication of social life as a result of his own openness and generosity of reason and love. It suggests that education needs to take into account the social group and needs to prepare pupils to take their place there. To accompany the development of a human person in the social sphere, awakening and confirming their sense of freedom, duty, and responsibility is the essential aim of education. 'For human life there is indeed nothing greater than intuition and love. ${ }^{64}$ While morality is steeped in reason and intelligence, it depends a great deal upon charity and love. ${ }^{65}$ If education is in the first place a service of help to human nature which acquires its own developed form in man, then the task of a pedagogue is well represented by his original service position (Gr. paidagógos): to lead out the hidden riches of the soul, which it was not even aware of itself, towards the light.

\section{Discussion and Conclusions}

Maritain's reflection of the educational situation of his period offers several areas of thought that appear to be, considering the current situation of culture and pedagogy, undoubtedly inspiring and valid perhaps even more now than at the time of their origination. Here are their brief summarisations:

- Maritain maintains a balanced approach to historical circumstances, avoiding catastrophic pessimism on one hand (according to which education would have no sense in a society

63 Ibid., p. 38.

64 Ibid., p. 23.

65 MARITAIN, The Education of Man ..., p. 125. 
made for cessation) and an uncritical and naïve optimism on the other hand (according to which nothing should be changed in the current state of education, for it is being carried out in the best way possible). This approach, expressed by the metaphor of a crossroads, enables the problematisation of education, taking a stand of axiological differentiation, and searching for ways of improvement. ${ }^{66}$ The approach of differentiation is urgent mainly in moments of crisis, like the civilisation transformation that is currently taking place.

- In the work 'Pour une philosophie de l'éducation', besides the etatist crisis of the totalitarianism of the war period, the crisis of the coming technocratic totalitarianism of consumer society, or the society of emptiness, is also mentioned. ${ }^{67}$ Maritain warns against the domination of educational means at the expense of the philosophical reflection of educational aims and he calls for a coexistence of empirical approaches (natural sciences and humanities, technology) and ontological approaches (philosophy and theology of education). Education is supposed to serve the 'awakening of man' and not his subordination of heteronomous purposes.

- While scientific and technological approaches to education are considered obvious today, the meaning of philosophy of education is neglected or even denied. Maritain reveals reductionist temptations of scientism and technocracy and emphasises the irreplaceable role of philosophical thinking in order that integrity of educated man was maintained and strengthened. A pedagogical discourse that rejects the philosophical component, holding it as non-scientific and abstract is a discourse that is partial and, in the end, it is a pseudo discourse.

- If pedagogy is a theory of the humanisation of man, then it requires an adequate conception of man - a conception that integrates an empirical knowledge of humanities and the development of man (psychology, sociology, etc.) with an ontological knowledge of nature and the existential situation of man (philosophy, religion). Pedagogy must not absolutise the contribution of psychology, sociology, and technology, which is massively taking place at present, since it will lose the finality of education out of sight and it risks its own instrumentalisation.

- Regarding the complexity of pedagogy, philosophy of education is legitimised from an epistemological, anthropological, and axiological perspective. ${ }^{68}$ From the epistemological perspective, the variety of approaches to education demands a philosophical metascientific reflection that offers a synthetising point of view at the same time. From the anthropological perspective, the notions of the lifelong learning and knowledge society demand a closer connection of pedagogy and anthropology, as well as pedagogy and social sciences. Personalistic anthropology, offered by Maritain, composes man as a person in a community, between the extremes of individualism and collectivism, or socialism and liberalism. From the axiological point of view, the contemporary crisis of education and school repeatedly reveals the need for an ethical and moral dimension of education that cannot do without philosophical reflection.

- A certain objection against Maritain may be represented by the fact that the author was not a pedagogue in the real sense of the word, thus, he did not elaborate a pedagogical theory

66 Cf. reflection of crisis as an opportunity for understanding the essence of a phenomenon according to Hannah Arendt in the work Between past and future: eight exercises in political thought. New York: Viking Press, 1968.

67 Cf. Gilles LIPOVETSKY, Lère du vide: Essais sur l'individualisme contemporain, Paris: Gallimard, 1983; Zygmunt BAUMAN, Liquid Times: Living in an Age of Uncertainty. Cambridge: Polity Press, 2007.

68 Cf. Giancarlo GALEAZZI in Jacques MARITAIN, Per una filosofia dell'educazione. Brescia: La Scuola, 2001, p. 14. 
with all its aspects, but among other themes, he philosophically dealt with the theme of education. Therefore, the impact and topicality of his thinking, relating education needs to be evaluated exclusively in the horizon of philosophy, philosophy of education, and not pedagogy in all its dimensions. On the other hand, Maritain's sense of interdisciplinarity of pedagogical thinking in contrast to the reductionist, scientific-technological, and praxocentric understanding of education needs to be highlighted. In this sense, the particularity of his conception of education appears.

- Another objection could be directed at certain (neo-Thomist) perennialism and traditionalism, which eventually always wins over progressivism in the author's thoughts, expressed in a positive approach to democracy and civic freedom. It needs to be stressed that Maritain is not closed to modernism, however, he does not tend towards pre-modernism. His position cannot be classified either within pre-modernism or neo-modernism, and not even nihilistic postmodernism, but he steps forward towards a certain type of late modernism or ultramodernism, connecting modernity and classicality, assimilating the conquests of modern sciences to the horizon of classical values.

- Other critical places could include his reservedness to contemporary pragmatic pedagogical movements, highlighted in the American reform pedagogy and European 'new schools'. However, not even here can Maritain be blamed for the rejection of or contempt for innovative educational methods - Maritain highly appreciates their effectivity: 'they are generally much better than those of the old pedagogy', and even, 'they are so good that we lose sight of the end?. ${ }^{69}$ What matters to the author is not the destruction of modern creative methods but their integration in a system focused on the accomplishment of humanistic aims: practical wisdom, reasonable autonomy, social responsibility. Otherwise, they would slip into paedocentrism, spontaneism, and infantilism.

- I have a reservation about Maritain's reluctance to educate the moral character of pupils. ${ }^{70}$ As I pointed out above in the text, the training of good will and moral virtues, in particular the virtues of generosity, solidarity, and pro-social altruism, should not be left to intellectual understanding and the extracurricular sphere alone. School education should not give up the opportunity to assist in shaping the character of students.

The postmodern situation assigns an ethical demand to people - to protect the rights of everyone, opinion minorities in particular, to protect the right to self-expression. This demand is not easy and simple to fulfill. To learn to live in plurality and diversity and not to fall into resignation and primitive, comfortable relativism (that is asking for a new universal validity urgently) is a challenge to contemporary moral and social education.

Maritain's philosophy of education, based on the integral conception of man, does not deny the meaning of various (post)modern pedagogical theories, but it points out their unilaterality. It may play an inspiring role also for followers of contemporary 'psycho-technological' educational doctrines, regardless of the confessional affiliation of the author. The project of integral humanism refers to the personalistic notion of man as a person living in time and space, leaning towards a dimension that transcends time and space.

As I introduced my thesis at the beginning of this article concerning the parallelism between the two situations, Maritain's and ours, on the basis of the above analysis I confirm the possibility and suitability of a philosophical and pedagogical reflection analogous to that of Maritain. I have

69 MARITAIN, Education..., p. 3.

70 Ibid., pp. 26-28. 
also explained both contexts and the theoretical shift, especially in the field of moral education. The strength of Maritain's educational theory is the emphasis on the universal dignity of human beings, regardless of time, place, and circumstances. The same reservation concerns his concept of childhood and education being out of touch with social and developmental psychology, and his almost exclusive emphasis on content to the detriment of methods. He speaks about education based upon complex metaphysical theories, but with a limited view of everyday pedagogical experience. Nevertheless, his seven misconceptions can be used as a guide for teachers in a critical reflection upon their approach to educational practice.

\section{Contact}

Assoc. Prof. Andrej Rajský, Ph.d.

Trnava university in Trnava

Faculty of Education

Department of Educational Studies

Priemyselná 4, 91843 Trnava

arajsky@gmail.com 